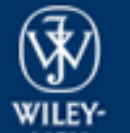

Fuel Cells

VCH

\title{
Study of the catalytic layer in Polybenzimidazole-based High Temperature PEMFC: Effect of Platinum content on the carbon support
}

\begin{tabular}{|r|l|}
\hline Journal: & Fuel Cells \\
\hline Manuscript ID: & fuce.200900088.R2 \\
\hline Wiley - Manuscript type: & Original Research Paper \\
\hline Date Submitted by the & 23-Dec-2009 \\
\hline Complete List of Authors: & $\begin{array}{l}\text { LOBATO, JUSTO; University of Castilla-La Mancha, Chemical } \\
\text { Engineering Department } \\
\text { Cañizares, Pablo; University of Castilla-La Mancha, Chemical } \\
\text { Engineering } \\
\text { Rodrigo, Manuel; University of Castilla-La Mancha, Chemical } \\
\text { Engineering } \\
\text { Linares, Jose; University of Castilla-La Mancha, Chemical } \\
\text { Engineering } \\
\text { Ubeda, Diego; University of Castilla-La Mancha, Chemical } \\
\text { Engineering } \\
\text { Pinar, Francisco; University of Castilla-La Mancha, Chemical } \\
\text { Engineering }\end{array}$ \\
\hline Keywords: & $\begin{array}{l}\text { Catalyst Layer, High Temperature, PBI, Pt/Vulcan Catalyst, } \\
\text { Electrochemical Surface Area (ESA) }\end{array}$ \\
\hline \hline
\end{tabular}

\section{S) ScholaroNE \\ Manuscript Central}



PEMFC: Effect of Platinum content on the carbon support.

3 Justo Lobato*, Pablo Cañizares, Manuel A, Rodrigo, José J. Linares, Diego Úbeda and F. Javier. Pinar. Cela, $n$ 12. 13071, Ciudad Real (Spain).

7 * Corresponding author: Phone: +34 926295300 Ext. 3418. Fax: +34 926295256.

8 Email: Justo.Lobato@uclm.es

\section{ABSTRACT}

10 In this work, the effect of platinum percentage on the carbon support of commercial 11 catalyst for electrodes to be used in a Polybenzimidazole (PBI)-based PEMFC has been 12 studied. Three percentages were studied (20\%, $40 \%$ and $60 \%)$. In all cases, the same 13 quantity of PBI in the catalyst layer was added, which is required as a "binder". From

$14 \mathrm{Hg}$ porosimetry analyses, pore size distribution, porosity, mean pore size, and tortuosity 15 of all electrodes were obtained. An increase in the amount of mesopores the lower is the 16 platinum percentage in the catalytic layer, which reduced the overall porosity, the mean 17 pore size, and increased the tortuosity. The electrochemical characterization was 18 performed by voltamperometric studies, assessing the effective electrochemical surface

19 area of the electrodes, by impedance spectroscopy (IS), determining the polarization

20 resistance, and by the corresponding fuel cell measurements. The best results were 21 obtained for the electrodes with a content of $40 \% \mathrm{Pt}$ on carbon, as a result of an 22 adequate combination of catalytic activity and mass transfer characteristics of the electrode. It has been demonstrated that the temperature favours the fuel cell 24 performance, and the humidification does not have remarkable effects on the 


\section{Introduction}

2

3 In recent years, there has been an intense research interest in the development of high

4 temperature $\left(>120^{\circ} \mathrm{C}\right)$ polymer electrolyte membrane fuel cells (HT-PEMFC's). This is

5 due to the numerous advantages of a PEMFC technology operating above $100{ }^{\circ} \mathrm{C}$ :

6 kinetics of both electrode reactions are enhanced [1, 2], no need for humidification [3],

7 tolerance of the $\mathrm{Pt} / \mathrm{C}$ electrodes to carbon monoxide is increased (when a fuel cell is

8 operated at $200{ }^{\circ} \mathrm{C}$, even $1 \% \mathrm{CO}$ in the reformate gas does not deteriorate the fuel cell

9 performance), and the integration of a PEMFC with a methanol reformer is more simple

10 [4]. Three different types of membranes are being investigated for operating at

11 temperature higher than $100^{\circ} \mathrm{C}$ : modified perfluorosulphonated membranes, alternative

12 sulphonated polymers and their composite, and finally acid-base polymer membranes $13[1,5]$.

14

15 The poly[2,2-(m-phenylene)-5,5-bibenzimidazole] (named commonly 16 polybenzimidazole, PBI) is a serious candidate for being used in HT-PEMFCs because

17 of its low-cost and high operational temperature. The key for the proton conduction in 18 polybenzimidazole-based membranes is their impregnation with an acid [6-10]. PBI

19 membranes doped with phosphoric acid are able to work at temperatures up to $200^{\circ} \mathrm{C}$.

20 Our group has been working on the synthesis of membranes for their use in PBI-based 21 HT-PEMFC's during the recent years [5, 8-11].

23 As it is well known, the membrane-electrode-assembly is the heart of a fuel cell. This

24 consists of several elements susceptible of being studied for the optimization of a fuel

25 cell performance. One of them is the catalyst layer, where the electrochemical reactions 
take place in it, and whose formulation must be optimized in order to improve the

2 performance of the PEMFC's $[6,12]$. To catalyse the reactions that take place on the

3 PEMFC, platinum is the most active noble metal. It is the catalyst surface area that

4 matters, not the weight, so it is important to have small platinum particles with large

5 surface area finely dispersed on the catalyst support surface, typically carbon powders.

6 In the last years, the great price of platinum and limited availability promote platinum

7 alloys with other metals, e.g. Pt-Ru, Pt-Sn, Pt-Cr, to decrease the platinum loading on

8 the catalyst layer, or a better distribution of the platinum added. However, performances

9 of these alloys are lower than those obtained with pure platinum for hydrogen oxidation

$10[13,14]$. Other alternative is the use of different catalyst deposition techniques to

11 decrease the catalyst loading on the electrodes [15]. Another element of the catalyst

12 layer is the polymeric "binder". This acts like a link between the catalyst particles,

13 avoids the agglomeration of catalyst particles, and favours the formation of the three

14 boundary surface if protons can travel along it, enhancing the activity of the catalyst

15 active sites, so that the own polymer electrolyte is normally used as "binder" [16-18].

17 In order to optimize the composition of the catalyst layer, the influence of Pt percentage on the carbon support on a PBI-based High Temperature PEMFC has been studied in

19 this work. Thus, electrodes with different platinum percentage on the carbon support, 20 and with the same PBI content, normalized with respect to the C/PBI weight ratio $21 \quad(\mathrm{C} / \mathrm{PBI}=20)$ (optimized in previous work [19]) were prepared. The electrodes were 22 characterized by Hg-porosimetry, and by different electrochemical techniques: cyclic voltammetry, polarization curves and impedance spectroscopy. 
1 Moreover, to study the effect of temperature and feed stream humidification, some tests

2 in a $5 \mathrm{~cm}^{2}$ single cell were also carried out at different cell temperatures, and humidifier

3 temperatures (keeping the cell temperature constant), using the optimum amount of

4 platinum under usual operation conditions.

5

\section{2. Experimental}

7 2.1. Preparation of the membrane-electrode-assemblies

8 On top of a gas diffusion media (Toray Graphite Paper, TGPH-120, $350 \mu \mathrm{m}$ thick, 10\%

9 wet-proofing, BASF Fuel Cell, Inc.), a microporous layer (MPL) was deposited by $\mathrm{N}_{2}$ -

10 spraying, consisting of $2 \mathrm{mg} / \mathrm{cm}^{2}$ Vulcan XC-72R Carbon Black (Cabot Corp.) and 10\%

11 PTFE (Teflon ${ }^{\text {TM }}$ Emulsion Solution, Electrochem Inc.). Next, the catalytic layer was

12 also deposited by $\mathrm{N}_{2}$-spraying, composed of Pt/C catalyst (20, 40 and $60 \% \mathrm{Pt}$ on

13 Vulcan XC-72R Carbon Black, ETEK-Inc.), PBI ionomer (3.7 wt. \% PBI in $N, N_{-}-$

14 dimethylacetamide, DMAc), and DMAc as solvent. In order to improve the $\mathrm{N}_{2}$-spray

15 process to avoid the electrodes flooding, the electrodes were heated at 60 and $90{ }^{\circ} \mathrm{C}$ for

16 spray the microporous and catalyst layer respectively. In all cases, the Pt loading on

17 both electrodes was $0.5 \mathrm{mg} \mathrm{Pt} / \mathrm{cm}^{2}$, a C/PBI weight ratio of 20 was used, electrode area

18 was $5 \mathrm{~cm}^{2}$, the DMAc volume added as ink solvent was $25 \mathrm{ml}$, and the platinum loading

19 was controlled by the electrode weight increase. Once deposited all the layers, the

20 electrodes were dried at $190{ }^{\circ} \mathrm{C}$ for 2 hours. Afterwards, the electrodes were wetted with

21 a solution of $10 \% \mathrm{H}_{3} \mathrm{PO}_{4}$, and left to absorb the acid for one day. The electrodes

22 prepared were divided into four pieces. Two of them were used to prepare the

23 membrane-electrode-assembly (MEA), whereas the other two were used for the

24 structural studies [11]. 
1 For the preparation of the MEA, a PBI membrane was taken out from a $75 \mathrm{wt}$ \%

2 phosphoric acid bath. Doping level acquired by the membrane was 6.6 molecules of

3 acid per polymer repeating unit. The superficial acid onto the membrane was thoroughly

4 wiped off with filter paper, and subsequently, it was used to prepare the MEA. The

5 doped membrane was sandwiched between two electrodes, hot-pressing the whole

6 system at $150{ }^{\circ} \mathrm{C}$ and $100 \mathrm{~kg} / \mathrm{cm}^{2}$ for $15 \mathrm{~min}$. Once the MEA was ready, it was inserted 7 into the cell.

8

\section{2.2. Structural Characterization}

$10 \mathrm{Hg}$-porosimetry analyses were performed on a Micromeritics AutoPore IV 9500 and the 11 electrode pore size distribution was obtained.

13 2.3. Fuel Cell Tests

14 Cell hardware consisted of two bipolar plates made of graphite (Sofacel, Spain), into 15 which it was machined channels with parallel geometry. Within the graphite plates, 16 heating rods were fitted in order to heat the fuel cell up. During the measurements, the

17 fuel cell was fed with pure hydrogen and oxygen, at a $0.134 \mathrm{l} / \mathrm{min}$ for $\mathrm{H}_{2}$, and 0.076 and $180.4 \mathrm{l} / \mathrm{min}$ for $\mathrm{O}_{2}$ and air, respectively, at atmospheric pressure. Temperature was 19 controlled with the aid of a temperature controller (CAL 3300, Cal Controls Ltd., U.K) $[11,20]$.

22 The procedure to perform polarization curves and impedance spectra can be depicted as 23 follows. Firstly, the fuel cell was kept at constant temperature $\left(125^{\circ} \mathrm{C}\right)$ for $24 \mathrm{~h}$, 24 monitoring the cell voltage at a constant current density of $0.215 \mathrm{~A} / \mathrm{cm}^{2}$, with a 25 potentiostat/galvanostat Autolab PGSTAT30 (Ecochemie, The Netherlands). 
1 Measurement of the effective electrode electrochemical surface area (ESA) was carried

2 out by cyclic voltammetry (CV), using humidified $\mathrm{N}_{2}(200 \mathrm{ml} / \mathrm{min})$ through the cathode

3 (working electrode), and humidified $\mathrm{H}_{2} \quad(134 \mathrm{ml} / \mathrm{min})$ through the anode

4 (counter/reference electrode), at room temperature. The effective electrochemical

5 surface area, ESA $\left(\mathrm{m}^{2} / \mathrm{g} \mathrm{Pt}\right)$, is given by the following formula:

6

$$
E S A=\frac{A_{P t}}{v C} \frac{1}{L_{e}}
$$

7 The parameter $\mathrm{A}_{\mathrm{Pt}}\left(\mathrm{A} \cdot \mathrm{V} / \mathrm{cm}^{2}\right)$ is the area under the hydrogen desorption peak obtained

8 by the $\mathrm{CV}$ measurements, $\mathrm{v}(\mathrm{V} / \mathrm{s})$ is the sweep rate, $20 \mathrm{mV} / \mathrm{s}, \mathrm{C}$ represents the charge

9 required to reduce a monolayer of protons on active platinum, $0.21 \mathrm{mC} / \mathrm{cm}^{2}$, and $\mathrm{L}_{\mathrm{e}}(0.5$

$10 \mathrm{mg} \mathrm{Pt} / \mathrm{cm}^{2}$ ) is the platinum load in the catalyst layer.

11

12 Fuel cell studies were carried out in the cell at $125^{\circ} \mathrm{C} .20 \% \mathrm{Pt} / \mathrm{C}$ was selected in the

13 electrode that was not optimized, i.e., it was selected as reference electrode for all

14 measurements, in order to compare with the results obtained for the electrode under

15 optimisation $(20,40$, and $60 \% \mathrm{Pt} / \mathrm{C})$. Impedance Spectra (IS) were performed at a

16 potential of $0.6 \mathrm{~V}$, running $\mathrm{O}_{2}$ or air through the cathode (working electrode), and $\mathrm{H}_{2}$ in

17 the anode (counter/reference electrode), under the fuel cell conditions. Frequency

18 ranged from $10 \mathrm{kHz}$ down to $100 \mathrm{mHz}$, with a potential wave of $10 \mathrm{mV}$ rms [5].

20 The temperature effect on fuel cell performance was analysed by increasing the cell

21 temperature in the uprising sequence $125,150,175$ and $200{ }^{\circ} \mathrm{C}(398,423,448$, and 473

$22 \mathrm{~K}$, respectively). For the study of the humidification, either the oxidant or the fuel

23 streams were humidified, by bubbling them through hot water chambers. The

24 temperatures of the water chambers in this study were 50 and $90^{\circ} \mathrm{C}$. 
4 3. Results and discussion

\subsection{Pore size distribution of the electrodes}

6 The results obtained for the pore size distribution by $\mathrm{Hg}$-porosimetry for the three

7 electrodes are shown in Figure 1. Only the pores ranging between 7 to $1000 \mathrm{~nm}$ has

8 been scaled, since pores larger than this size are related to the macroporous carbon

9 support $[21,22]$. In this range, porosity is due to the microporous and catalytic layer

10 [23].

12 Micropores are defined as pores of less than $2 \mathrm{~nm}$, being from 2 to $100 \mathrm{~nm}$ the size of

13 mesopores. It can be seen that the majority of pore ranges from 50 to $120 \mathrm{~nm}$, which

14 indicates the existence of a marked mesoporosity in the catalytic/microporous layer

15 independently of the Pt content on the carbon support. This corresponds with the space

16 between the particles that form the catalyst, i.e., between the carbon particles [23, 24].

17 Logically, the lower the platinum percentage (higher carbon content), the larger amount of mesopores that are present in the electrode.

\section{Figure 1}

21 Table 1 collects the values of the overall porosity, tortuosity, and mean pore size of the

22 three electrodes. Before analyzing these results, it is important to point out that the

23 higher the platinum percentage in the catalyst layer (the lower the carbon content), the

24 thinner the catalyst, and therefore, the preponderance of the macroporous carbon

25 support becomes larger. This explains the increase in the overall porosity of the sample, 
1 and in the mean pore size as the platinum percentage increases. On the other hand, a

2 thinner catalyst makes the transport of any fluid less tortuous.

\section{Table 1}

\section{3.2. Effective Electrochemical surface area}

5 The ESA of electrodes prepared with different Pt content catalyst was evaluated by

6 cyclic voltammetry measurements, from the hydrogen desorption peaks of the

7 voltamogramms (not shown). Table 1 collects the different ESA values obtained for the

8 different electrodes prepared. It can be observed that as the platinum percentage

9 increases, the ESA decreases. The higher the platinum percentage in the catalyst, the

10 larger the platinum particle size becomes (see Table 1), resulting in a lower catalyst

11 surface area. This could explain the decrease in the ESA. Values of the catalyst

12 utilisation are also shown in Table 1 . The catalyst utilisation slightly increases as the

13 platinum percentages also does. Despite this slight larger utilisation, the absolute values

14 of the ESA lower. On the other hand, the similarities in the values of the catalyst

15 utilisation may be an indication of a similar distribution of all the elements that form the

16 catalytic layer (platinum, carbon, PBI, and phosphoric acid) independently of the

17 platinum percentage of the catalytic layer. Prasanna et al. [25] and Ralph and Hogarth

18 [26] observed the same behaviour of the electrochemical active surface as the platinum

19 percentage in the catalyst increases.

21 3.3. Influence of the platinum percentage in the cathode catalyst on the cell

\section{2 performance}

23 Figure 2a shows the polarization curves carried out with cathode prepared with different

24 Pt percentages on carbon support when oxygen was used as comburent. In the anode, it 25 was used in the catalyst layer a $20 \%$ of platinum on carbon support, and the same PBI 
1 content than in the cathode $(\mathrm{C} / \mathrm{PBI}=20)$. Slight fuel cell performance improvement was

2 obtained when the platinum percentage in the catalyst was increased from 20 to $40 \%$.

3 This could be due to the reduction in the catalytic layer thickness, facilitating the access

4 of reactant gases towards the catalyst active sites. Electrode thickness can be assumed

5 proportional to carbon loading, since most of the catalytic layer thickness comes from

6 the carbon support, which, in this range of platinum percentage in the catalyst, is nor far

7 from reality [18]. The carbon loading for each electrode was: $2,0.75$ and $0.33 \mathrm{mg} \mathrm{C} / \mathrm{cm}^{2}$

8 for 20,40 and $60 \% \mathrm{Pt} / \mathrm{C}$ respectively. An estimation of the catalytic layer thickness is

9 collected in Table 1, calculated from the carbon loading, the density of the Vulcan XC-

$1072 \mathrm{R}$ carbon black $\left(6 \mathrm{lbs} / \mathrm{ft}^{3}\right)$, and the BET surface area $\left(250 \mathrm{~m}^{2} / \mathrm{g}\right)$ [27], assuming a

11 spherical geometry of the carbon particles. A lower catalyst layer thickness is expected

12 to lead to a reduction in the mass transport limitations. Another reason that may lead to

13 the slight improvement of the fuel cell results for the $40 \% \mathrm{Pt} / \mathrm{C}$ catalyst is the

14 observation mentioned by Kongstein et al. [28]. They observed that a mixed catalytic

15 layer, with a combination of a $50 \% \mathrm{Pt} / \mathrm{C}$ catalyst in the proximities of the interface

16 electrode-membrane, and a $20 \% \mathrm{Pt} / \mathrm{C}$ in the zone close to the gas diffusion layer,

17 performed the best. The use of the $40 \% \mathrm{Pt} / \mathrm{C}$ might be a "similar approach" (despite its

18 lower ESA), as it lies between the two previous vales, larger concentration of platinum

19 sites than $20 \% \mathrm{Pt} / \mathrm{C}$ in the membrane-electrode interface, and a lower concentration of

20 the catalyst in the proximities of the gas diffusion layer. According to Seland et al [18],

21 the Pt active sites in contact with the membrane are the zones where the higher weight

22 of the electrochemical reactions takes place.

$23 \quad$ Figure 2 
1 By contrast, the $60 \% \mathrm{Pt} / \mathrm{C}$ electrode shows the lowest performance. This can be

2 explained in terms of the lower ESA of the electrodes, and, in consequence, the lower

3 electrochemical activity of the electrode. This result resembles with that of Paganin et

4 al. [29], who also observed the performance deteriorated as the Pt/C ratio was increased

5 beyond $40 \%$ for a low temperature PEMFC.

6

7 When air was employed as comburent (Figure 2b), it was observed a similar behaviour

8 of the system. Thus, the same reasons exposed above may be used to explain the fuel

9 cell performance when air is the comburent, though in this case, the decrease on fuel

10 cell performance at high current densities between the samples with $20 \%$ and $40 \%$ on

11 platinum percentage in the catalyst layer is higher. The use of air may emphasize the

12 effect of a thicker catalytic layer, enlarging the differences between these two platinum

13 percentages.

14

15 Table 1 collects the values of the Tafel slopes of the different polarization curves in

16 order to compare each electrode performance, after fitting the experimental cell voltage

17 (E) data to the semi-empirical equation $E=E_{0}-b \cdot \log (j)-R \cdot j$, where $E_{0}$ is the open

18 circuit voltage, $b$ is the Tafel slope, related to the electrode performance when the rate-

19 limiting step is the electrocatalytic reaction, $R$ is the slope of the linear region of the

20 polarization curves (related to the ohmic resistance of the system, but also can contain

21 small contributions coming from linear mass transport limitations, and from the

22 polarization resistance of the hydrogen oxidation reaction [30]), and $j$ is the current

23 density. As it can be seen, the lowest Tafel slope is obtained, both in the case of oxygen,

24 and air, for the electrode prepared with a catalyst $40 \% \mathrm{Pt} / \mathrm{C}$, showing the best efficiency

25 of this electrode for the electrochemical reactions. 
2 A simple way to evaluate the oxygen transport across the electrodes, and therefore the

3 mass transfer is through the oxygen gain parameter [31, 32], quantifiable by the

4 Equation 2.

$$
\Delta V\left(O_{2} / A i r\right)=V_{O_{2}}(i)-V_{A i r}(i)
$$

6

7 The parameter $\Delta V\left(O_{2} /\right.$ Air $)$ is the oxygen gain, $V_{O_{2}}(i)$ represents the cell potential for a

8 current density when oxygen was used as comburent, and $V_{A i r}(i)$ is the potential when

9 air was used as comburent at the same current density. Thus, better oxygen access to the

10 catalyst active sites is obtained for small values of the oxygen gain at high current

11 densities. Figure 3 shows the values obtained for the oxygen gain.

\section{Figure 3}

14 It can be observed that the cathode with a catalyst layer with a $20 \%$ of platinum on the

15 carbon support has the largest oxygen gain at high current densities, which indicates a

16 limited oxygen transport due to the highest thickness of this electrode. The $60 \% \mathrm{Pt} / \mathrm{C}$

17 on catalyst layer sample has a similar oxygen gain than $40 \% \mathrm{Pt} / \mathrm{C}$ sample, despite lower

18 values may be expected. As Prasanna et al.[25] mentioned, this result implies that the

19 expected decrease in the mass transport limitations can not balance the lower ESA,

20 which enlarges its influence when air is used.

22 In order to further support the fuel cell results, Nyquist plots of the different electrodes,

23 for both oxygen, and air, are displayed in Figure 4, under the same fuel cell performance

24 conditions. A very good approach to evaluate the suitability of a catalytic layer is by

25 polarization resistance obtained from impedance spectroscopy, since this is composed 
1 by the charge transfer (linked to the kinetic of the electrochemical reaction), and the

2 mass transport processes that take place in the catalyst layer [33, 34] (through the

3 agglomerate of catalyst particle, and within the agglomerate, especially through the

4 thin-film of electrolyte surrounding the catalyst sites [11, 35]). Table 1 also shows the

5 polarization resistances, after fitting the experimental data to the equivalent circuit

6 showed in Figure 4a, described elsewhere [19].

$7 \quad$ Figure 4

8

9 As in the case of the Tafel slope, the lowest polarization resistance is achieved for the

$1040 \% \mathrm{Pt} / \mathrm{C}$ catalyst, indicating that this percentage of platinum gives the best

11 combination of catalytic activity, and mass transfer characteristic within the catalytic

12 layer, leading to the best fuel cell performance. In the case of the $20 \% \mathrm{Pt} / \mathrm{C}$, despite the

13 larger ESA, the thicker catalytic layer seems to impair the reactive gases access, and the

14 exit of the water vapour produced, resulting in a slight increase of the polarization

15 resistance. In the case of the $60 \% \mathrm{Pt} / \mathrm{C}$ catalyst, the polarization resistance notably

16 increases, which is attributed to the reduction in the ESA. Similarly to the oxygen gain,

17 the reduced catalytic activity of this electrode seems to depress the performance of this

18 electrode, in spite of the higher concentration of active sites in the interface of the

19 electrode-membrane, and the reduced thickness of the electrode.

20

21 3.3. Influence of the platinum percentage in the anode catalyst on the cell performance

22 A similar study was carried out in the anode side. Figure 5 shows the polarization and

23 power density curves of the different anodes prepared. As in the study of the cathode,

24 the highest performance was reached by the anode electrode prepared with a $40 \%$

25 platinum percentage on the catalyst, although the difference between anode samples are 
1 lower than between cathode samples. This behaviour is explained taking into account

2 that the oxygen reduction reaction mostly controls the performance in this kind of PEM

3 fuel cells [36]. Notwithstanding, contrary to perfluorosulphonated electrolyte-based

4 PEMFCs, due to the low hydrogen permeability of phosphoric acid-doped PBI and 5 more sluggish hydrogen oxidation kinetic [18], the anode can not be considered 6 negligible as it occurs in Nafion ${ }^{\circledR}$-based PEM fuel cells [37]. Nevertheless, in order to

7 explain fuel cell performance with the different platinum percentages in the anode, it

\section{1 cell when this anode is used.}

\section{Figure 5}

\subsection{Temperature and humidification fuel cell test}

15 A brief study of some operation variables was done to analyze the fuel cell 16 performance. Thus, fuel cell temperature, and cathode-anode humidification were

17 studied. Taking into account the previous results, both electrodes were prepared with catalyst that contained $40 \%$ of platinum on the Vulcan XC-72R carbon black support.

20 Figure 6 shows the temperature effect on the fuel cell performance. In this figure the

21 temperature was expressed in thermodynamic temperature, in other words, in Kelvin for

22 the analyses of the effect of the temperature. An increase in temperature improves fuel

23 cell performance due to, both the enhancement of the kinetics and diffusion processes,

24 and the increase of electrolyte conductivity $[1,8,18,28,38]$. On the other hand, it can

25 be observed that the enhancement on fuel cell performance is lower when temperature 
1 was increased. In order to help to interpret the results, the experimental data were fitted

2 to the semi-empirical model proposed previously to estimate the Tafel slopes. The

3 values of each parameter are collected in Table 2. In order to further evaluate the

4 catalytic activity, the exchange current density is also calculated from $\mathrm{E}_{0}$, by applying

5 the following expression: $E_{0}=E_{r}+b \cdot \log j_{0}$, where $E_{r}$ is the thermodynamic open circuit

6 voltage, and $j_{0}$ is the exchange current density, related to the reaction rate of the oxygen

7 reduction reaction [39].

\section{Table 2}

9

10 In Table 2, it can be seen that the exchange current density increases with the

11 temperature. This is due to the intrinsic enhancement of the electrocatalytic activity with

12 the temperature. In the case of the Tafel slope, the minimum value is achieved at $150^{\circ} \mathrm{C}$,

13 increasing at higher temperatures. In order to understand this behaviour, it will be firstly

14 analyzed the behaviour of the slope of the linear region of the polarization curves $(R)$,

15 mostly dependant on the electrolyte conductivity [2]. The higher the temperature, the

16 lower is $R$, due to the increase of the $\mathrm{H}_{3} \mathrm{PO}_{4}$ doped PBI membranes conductivity with

17 the temperature $[11,20]$. However, this increase slows down with the temperature. In

18 the conductivity measurements performed to $\mathrm{H}_{3} \mathrm{PO}_{4}$ doped PBI membranes, in some

19 cases [5], it has been reported that this decreases above $423 \mathrm{~K}$ when the measurements

20 were carried out under very low humid conditions, due to the self-dehydration of the

21 phosphoric acid, leading to the formation of the less conductive species pyrophosphoric

22 acid. Therefore, the lower increase in $R$ the higher the temperature could be explained in

23 terms of the more intense self-dehydration phenomenon of the phosphoric acid

24 (especially taking into account that the measurements were carried out from 398 to 473

$25 \mathrm{~K}$ ), which offsets the intrinsic increase of the electrolyte conductivity with the 
1 temperature. The electrolyte is also an active element in the electrode, since it transports

2 the protons within the catalytic layer. Therefore, the slight increase in the Tafel slope

3 with the temperature may be due to the own self-dehydration of the electrolyte

4 contained in the electrode, which does not result beneficial for the electrode

5 performance, despite the increase of the intrinsic catalytic activity with the temperature.

\section{Figure 6}

7

8 Figure 7 shows fuel cell performance when the cathode (Fig. 7a), and the anode (Fig.

9 7b) feed streams, were humidified at two different temperatures. The humidifier

10 temperatures chosen for this study were 50 and $90^{\circ} \mathrm{C}$.

\section{$11 \quad$ Figure 7}

13 The results obtained in this study are quite interesting. On the one hand, it can be

14 observed that humidifying the cathode hardly affects the cell performance.

15 Nevertheless, an increase in the humidity enhances the proton electrolyte conductivity

$16[1,5,8,35]$, and so does the oxygen solubility of PBI, which is strongly beneficial for

17 the diffusion of reactant gases to active sites [40]. This should lead to an enhancement

18 of the cell performance. However, the oxygen partial pressure drop that takes place

19 when feed streams are humidified, in addition to the water vapour generated on cathode,

20 may create a water vapour partial pressure in excess, reducing the oxygen partial

21 pressure, and hence, increasing the mass transport limitations and offsetting the

22 expected performance enhance.

24 In the case of the cathode, the effect of the humidification is more beneficial. This can

25 be explained taking into account that the anode works under completely dry conditions, 
1 and therefore, the presence of water vapour benefits its performance due to the increase

2 of the electrolyte conductivity, and also to the expected increase in the solubility of

3 hydrogen in the PBI. Nevertheless, when the temperature of the humidifier increases

4 from 50 to $90^{\circ} \mathrm{C}$, the cell performance almost keeps constant. Again, if the level of

5 humidification is too high, the partial pressure of the reactant drops too much, offsetting

6 the beneficial effects of a higher degree of humidification in the membrane-electrode-

7 assembly.

8

9 These results show that in the case of PBI-based high temperature PEMFC, the

10 pressurization to enable the increase of the operational temperature, and the pre-

11 humidification of the reactant streams, is not be required, making the system simpler

12 and cost-saving.

\section{4. Conclusions}

16 In this work, electrodes with different Pt percentage on the carbon support $(20,40$, and

$1760 \%$ ) were prepared, physicochemical and electrochemically characterized, and their

18 performance in an actual single fuel cell was tested.

20 Pore size distribution measurements seemed to preliminarily postulate the $60 \% \mathrm{Pt} / \mathrm{C}$ as

21 the most suitable catalyst in terms of mass transfer characteristics. On the other hand, as

22 the Pt content on carbon support increased, the ESA decreased, so that $20 \% \mathrm{Pt} / \mathrm{C}$

23 seemed to be the most active catalyst. Actual fuel cell test revealed that the optimum Pt

24 content on the carbon support was $40 \% \mathrm{Pt} / \mathrm{C}$ for both electrodes, as a result of the 
combination of a suitable catalytic activity, and mass transfer characteristics, leading to

2 the maximum fuel cell performance and minimum polarization resistance.

3

4 As it was expected, the higher the temperature, the better the cell performed, as a

5 consequence of the increase in the electrolyte conductivity and enhancement on the

6 reactions kinetic. Nonetheless, the higher the temperature, the lower was the

7 performance enhancement, due to a possible electrolyte dehydration phenomenon. From

8 humidification tests, it can be said that this is not required for the cathode, and only if

9 the fuel stream is humidified, a slight increase in the performance was observed.

10 Therefore, in the PBI-based systems, the humidification does not play an important role

11 on the cell performance.

\section{Acknowledgements}

14 Authors would like to thank the "Junta de Comunidades de Castilla-La Mancha

15 (JCCM)" and the Company CLM-H2 for the financial support through the Project 16 PBI08-151-2045. Also, authors would like to thank the Spanish Government

17 (Ministerio de Ciencia e Innovación) for the FPU grant AP2007-02713 awarded to 18 Diego Úbeda.

\section{References}

21 [1] Q. Li, R. He, J.O. Jensen, N.J. Bjerrum, Fuel Cells 4 (2004) 147.

22 [2] Q. Li, R. He, J.-A. Gao, J.O. Jensen, N.J. Bjerrum, J. Electrochem. Soc. 150 (2003)

23 A1599.

24 [3] M. K. Daletou, J. K. Kallitsis, G. Voyiatzis, S.G. Neophytides, J. Membrane Sci. $25 \quad 326(2009) 76$. 
1 [4] C. Pan, R. He, Q. Li, J. O. Jensen, N. J. Bjerum, H. A. Hjulmand, A. B. Jensen, J.

2 Power Sources 145 (2005) 392.

3 [5] J. Lobato, P. Cañizares, M.A. Rodrigo, J.J. Linares, J.A. Aguilar, J. Membr. Sci. 306 $4 \quad$ (2007) 47.

5 [6] R. Bouchet, E. Siebert, Solid State Ionics 118 (1999) 287.

6 [7] R. Bouchet, S. Miller, M. Duclot, J.L. Souquet, Solid State Ionics 145 (2001) 69.

7 [8] J. Lobato, P. Cañizares, M.A. Rodrigo, J.J. Linares, G. Manjavacas, J. Membr. Sci.

$8280(2006) 351$.

9 [9] J. S. Wainright, J. -T. Wang, D. Weng, R. F. Savinell, M. Litt, J. Electrochem. Soc.

$10142(1995)$ L121.

11 [10] J. -T. Wang, R. F. Savinell, J. Wainright, M. Litt, H. Yu, Electrochim. Acta 41

12 (1996) 193.

13 [11] J. Lobato, P. Cañizares, M.A. Rodrigo, J.J. Linares, Electrochim. Acta 52 (2007) 143910.

15 [12] J. Lobato, M.A. Rodrigo, J.J. Linares, K. Scott. J. Power Sources 157 (2006) 284.

16 [13] P. Costamagna, S. Srinivasan, J. Power Sources 102 (2001) 242.

17 [14] N. M. Markovic, T. J. Schmidt, V. Stamenkovic, P. N. Ross, Fuel Cells 1 (2001)

$18 \quad 105$.

19 [15] S. Litster, G. Malean, J. Power Sources 130 (2004) 61.

20 [16] E. Antolini, J. Appl. Electrochem. 34 (2004) 563.

21 [17] S. Litster, G. Mclean, J. Power Sources 130 (2004) 61.

22 [18] F. Seland, T. Berning, B. Børrensen, R. Tunold, J. Power Sources 160 (2006) 27.

23 [19] J. Lobato, P. Cañizares, M.A, Rodrigo, J.J. Linares, D. Ubeda, F.J. Pinar, Int. J. of 24 Hydrogen (In press, 2009). 
1 [20] J. Lobato, P. Cañizares, M. A. Rodrigo, J. J. Linares, C-G. Piuleac, S. Curteanu. J.

2 Power Sources 192 (2009) 190.

3 [21] J. Lobato, P. Cañizares, M.A. Rodrigo, C. Ruiz-López, J.J. Linares, J. Appl.

$4 \quad$ Electrochem. 38 (2008) 793.

5 [22] J. Lobato, P. Cañizares, M.A. Rodrigo, D. Úbeda, F. J. Pinar, J.J. Linares, Fuel

6 Cells (submitted 2009).

7 [23] H. Watanabe, M. Tomikawa, S. Motoo, J. Electroanal. Chem. 195 (1985) 81.

8 [24] J. Nordlund, A. Roessler, G. Lindbergh, J. Appl. Electrochem. 32 (2002) 259.

9 [25] M. Prasanna, H. Y. Ha, E. A. Cho, S. -A. Hong, I. -H. Oh, J. Power Sources 137

$10 \quad(2004) 1$.

11 [26] T.R. Ralph, M.P. Hogarth, Platinum Metal Reviews 46 (2002) 3.

12 [27] http://www.cabot-corp.com/wcm/download/en-us/sb/VULCAN_XC72R1.pdf

13 (Access on December 15, 2009)

14 [28] O.E. Kongstein, T. Berning, B. Brresen, F. Seland, R. Tunold, Energy 32 (2007) 15418.

16 [29] V.A. Paganin, E.A. Ticianelli, E.R. Gonzales, J. Appl. Electrochem. 26 (1996) 297.

17 [30] E. Antolini, R.R. Passos, E.A. Ticianelli, J. Appl. Electrochem. 32 (2002) 383.

18 [31] M. Prasanna, H.Y. Ha, E.A. Cho, S.-A. Hong, I.-H. Oh, J. Power Sources 131 $19 \quad$ (2004) 147.

20 [32] Y.-G. Yoon, G.-G. Park, T.-H. Yang, J.N. Han, W.-Y. Lee, C.-S. Kim, Int. J. Hyd. 21 Energy 28 (2003) 657.

22 [33] T.E. Springer, T.A. Zawodzinski, M.S. Wilson, S. Gottesfeld, J. Electrochem. Soc. $23143(1996) 587$.

24 [34] M. Ciureanu, R. Roberge, Phys J., Chem. B. 105 (2001) 3531. 
1 [35] J. S. Wainright, J.-T. Wang, D. Weng, R. F. Savinell, J. Electrochem. Soc. 142 2 (1995) L121.

3 [36] N. H. Jalani, M. Ramani, K. Ohlsson, S. Buelte, G. Pacifico, R. Pollard, R. Staudt, $4 \quad$ R. Datta, J. Power Sources 160 (2006) 1096.

5 [37] D. Cheddie, N. Munroe, Energy Conversion and Management 47 (2007) 1490.

6 [38] Q. Li, R. He, J. O. Jensen, N. J. Bjerrum, Chem. Mater. 15 (2003) 4896.

7 [39] T. Mennola, Thesis for the degree of Licenciate of Technology, Helsinki

8 University of Technology, November 2000.

9 [40] Z. Liu, J.S. Wainright, M.H. Litt, R.F. Savinell, Electrochem. Acta 51 (2006) 3914. 


\section{CAPTION FOR FIGURES}

2

3 Figure 1. Hg-porosimetry of the electrodes with different $\mathrm{Pt} / \mathrm{C}$ ratio.

4 Figure 2. Polarization curves for the different $\mathrm{Pt} / \mathrm{C}$ content in cathode catalyst layer.

$520 \% \mathrm{Pt} / \mathrm{C}$ in anode. Pt loading $=0.5 \mathrm{mg} / \mathrm{cm}^{2}$ on both electrodes. $\mathrm{T}=125^{\circ} \mathrm{C}$; (a) $\mathrm{O}_{2}$ was

6 used as comburent; (b) air was used as comburent.

$7 \quad$ Figure 3. Oxygen gain for different $\mathrm{Pt} / \mathrm{C}$ ratio in cathode catalyst layer.

$820 \% \mathrm{Pt} / \mathrm{C}$ in anode $\mathrm{T}=125^{\circ} \mathrm{C}$.

9 Figure 4. Nyquist plots of the different $\mathrm{Pt} / \mathrm{C}$ ratio in the cathode catalyst layer. (a)

10 Equivalent circuit; (b) $\mathrm{O}_{2}$ was used as comburent; (c) air was used as comburent.

11 Figure 5. Polarization curves for the different $\mathrm{Pt} / \mathrm{C}$ ratio in anode catalyst layer.

$1220 \% \mathrm{Pt} / \mathrm{C}$ in cathode. Pt loading $=0.5 \mathrm{mg} / \mathrm{cm}^{2}$ on both electrodes. $\mathrm{T}=125{ }^{\circ} \mathrm{C}$.

13 Comburent $=\mathrm{O}_{2}$.

14 Figure 6. Performance fuel cell at different temperatures. $40 \% \mathrm{Pt} / \mathrm{C}$ in both electrodes.

15 Platinum loading $=0.5 \mathrm{mg} / \mathrm{cm}^{2} . \mathrm{O}_{2}$ used as comburent.

16 Figure 7. Effect of humidification on a PBI-based high temperature PEMFC. $40 \%$ Pt/C

17 in both electrodes. Platinum loading $=0.5 \mathrm{mg} / \mathrm{cm}^{2} . \mathrm{O}_{2}$ used as comburent. $\mathrm{T}=125^{\circ} \mathrm{C}$.

(a) Cathode humidified at two temperatures; (b) Anode humidified at two temperatures.

Table 1. Different physical and electrochemical parameters of the electrodes prepared

\section{1 with different platinum percentage in the catalytic layer.}

22 Table 2. Influence of the temperature on the open circuit voltage, exchange current 


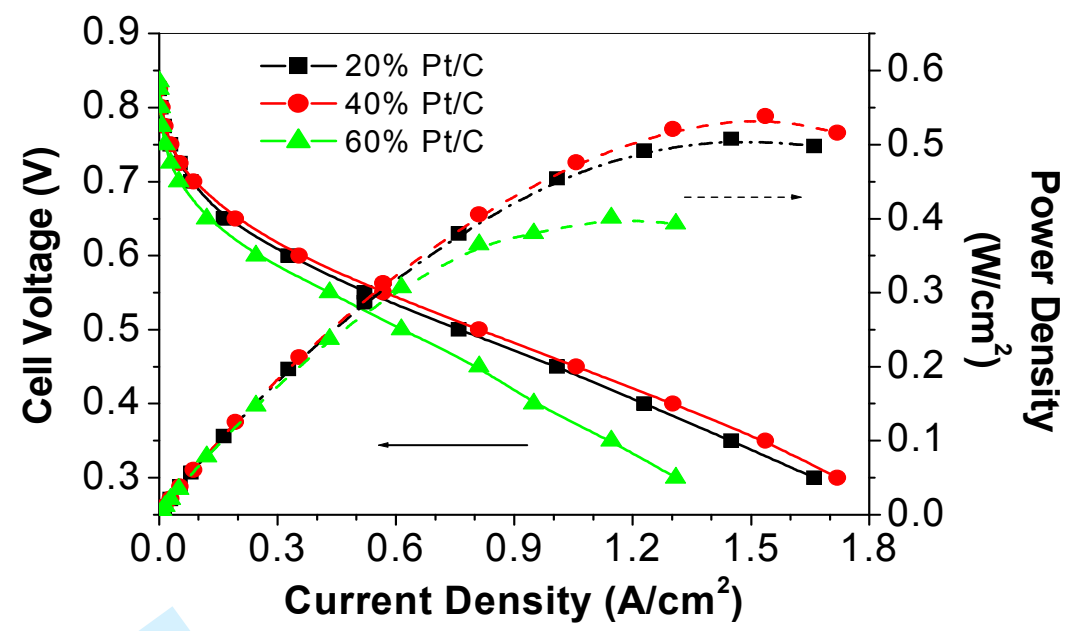

(a)

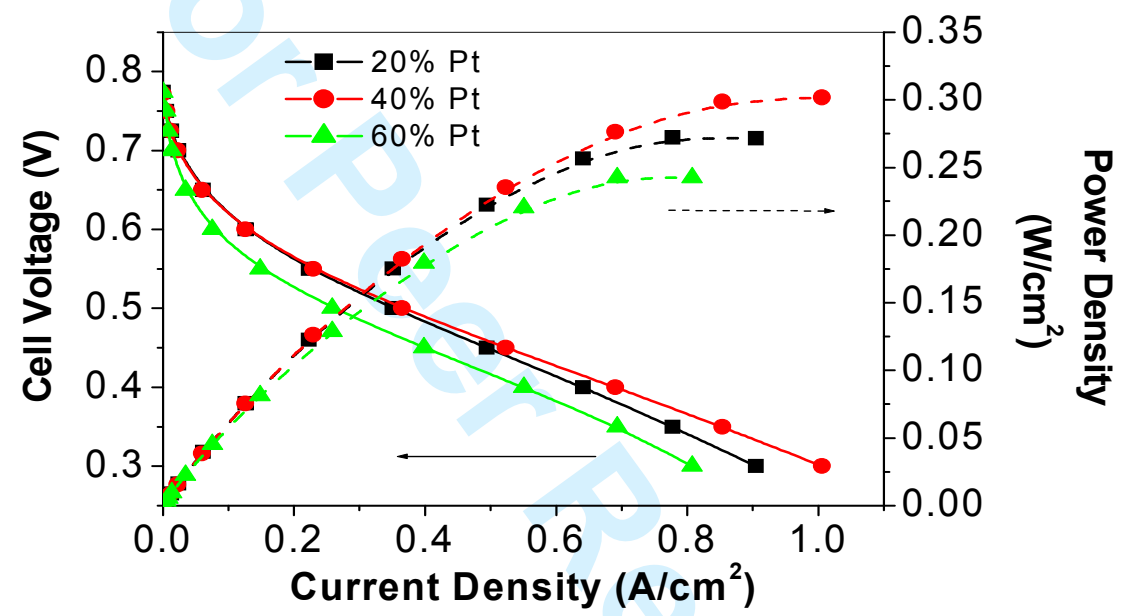

(b)

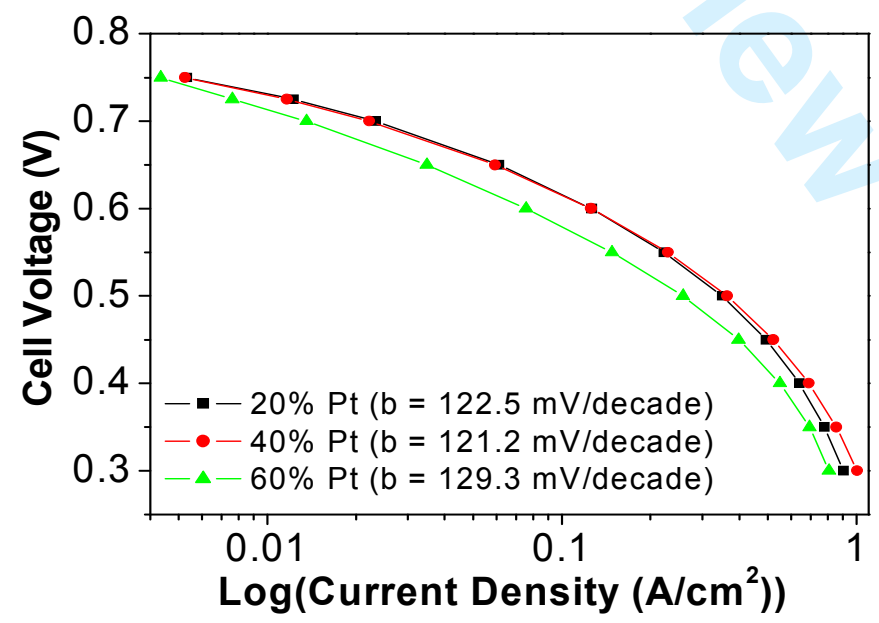

(c)

Figure 2 


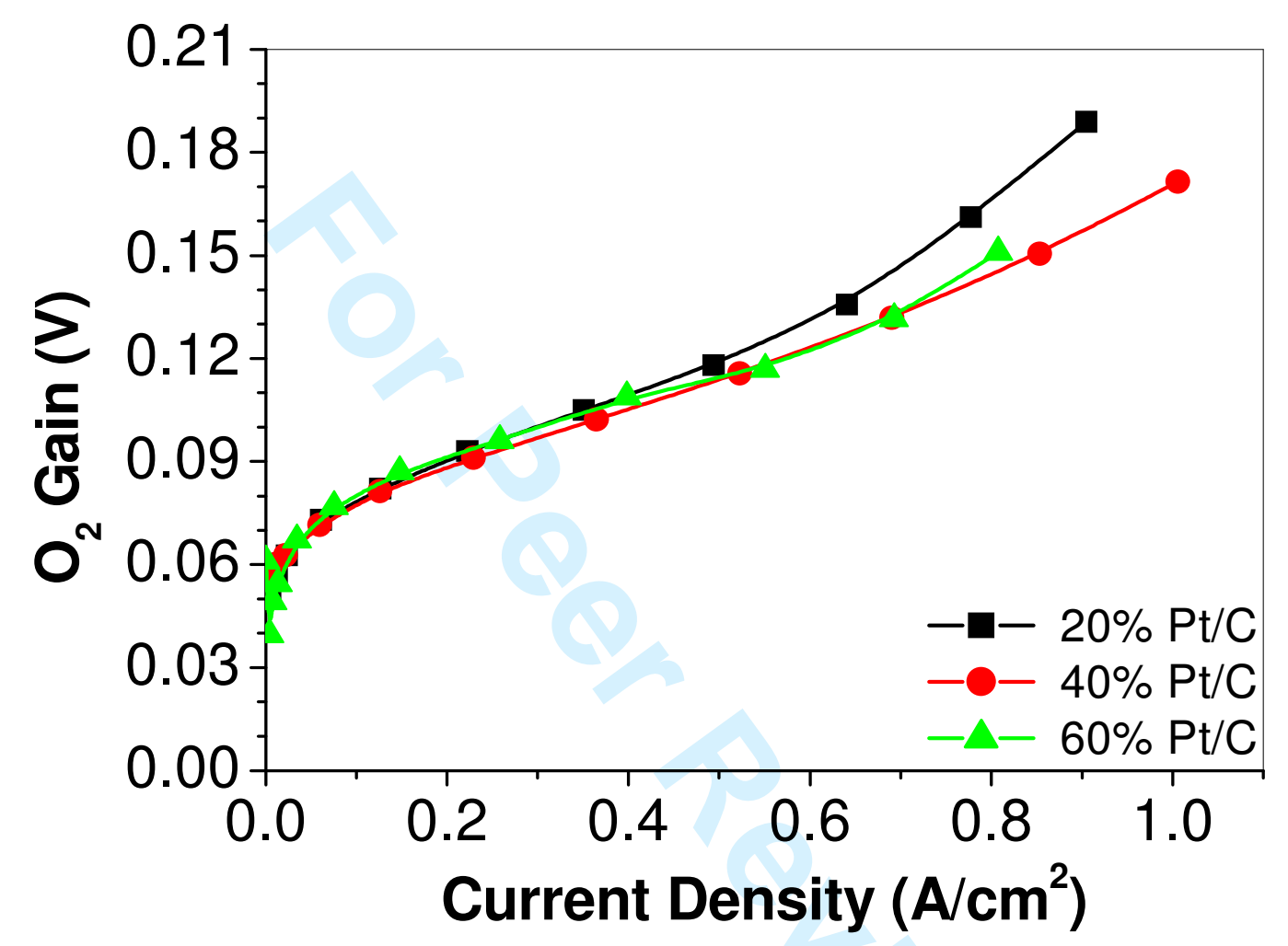

Figure 3 


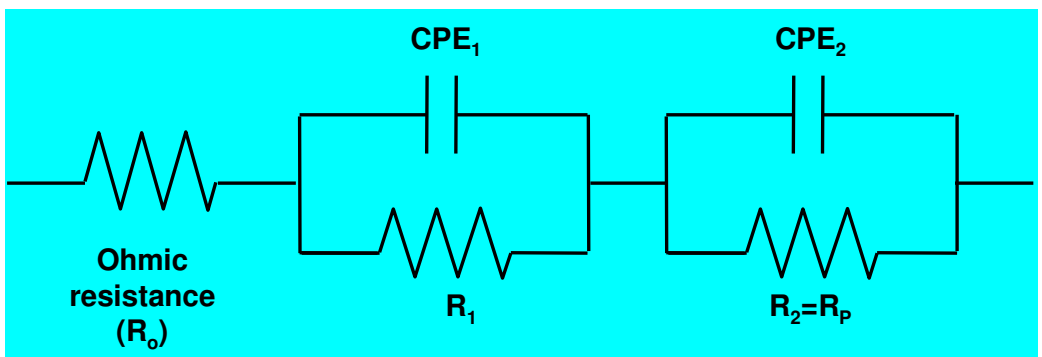

(a)

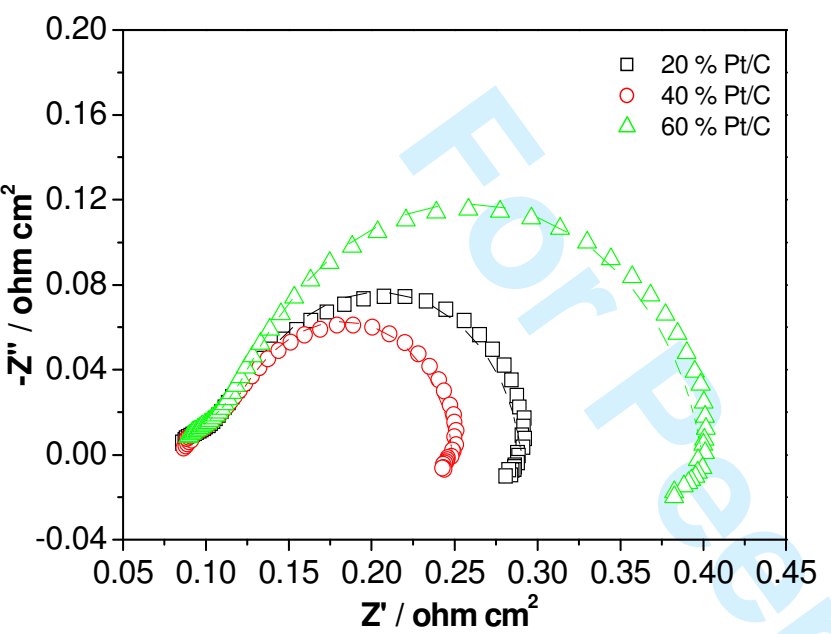

(b)

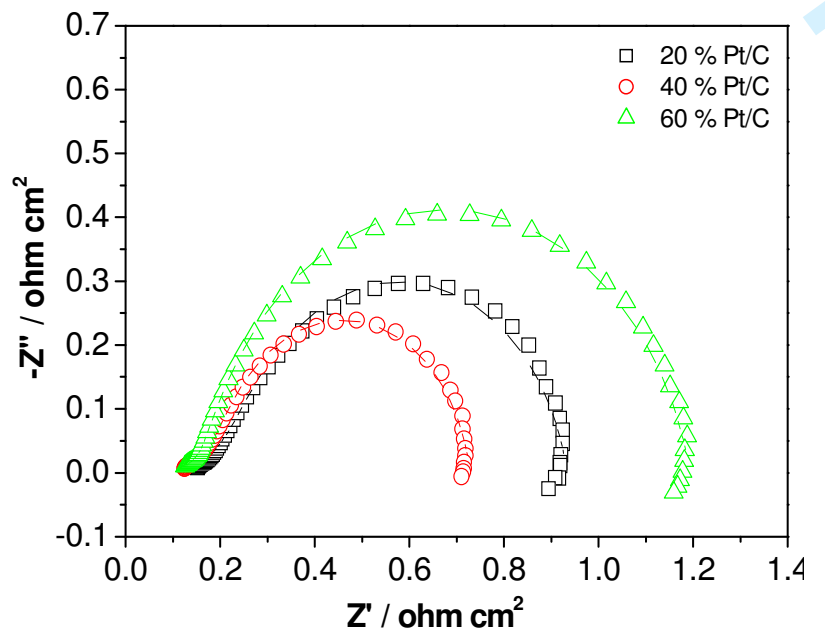

(c)

Figure 4 


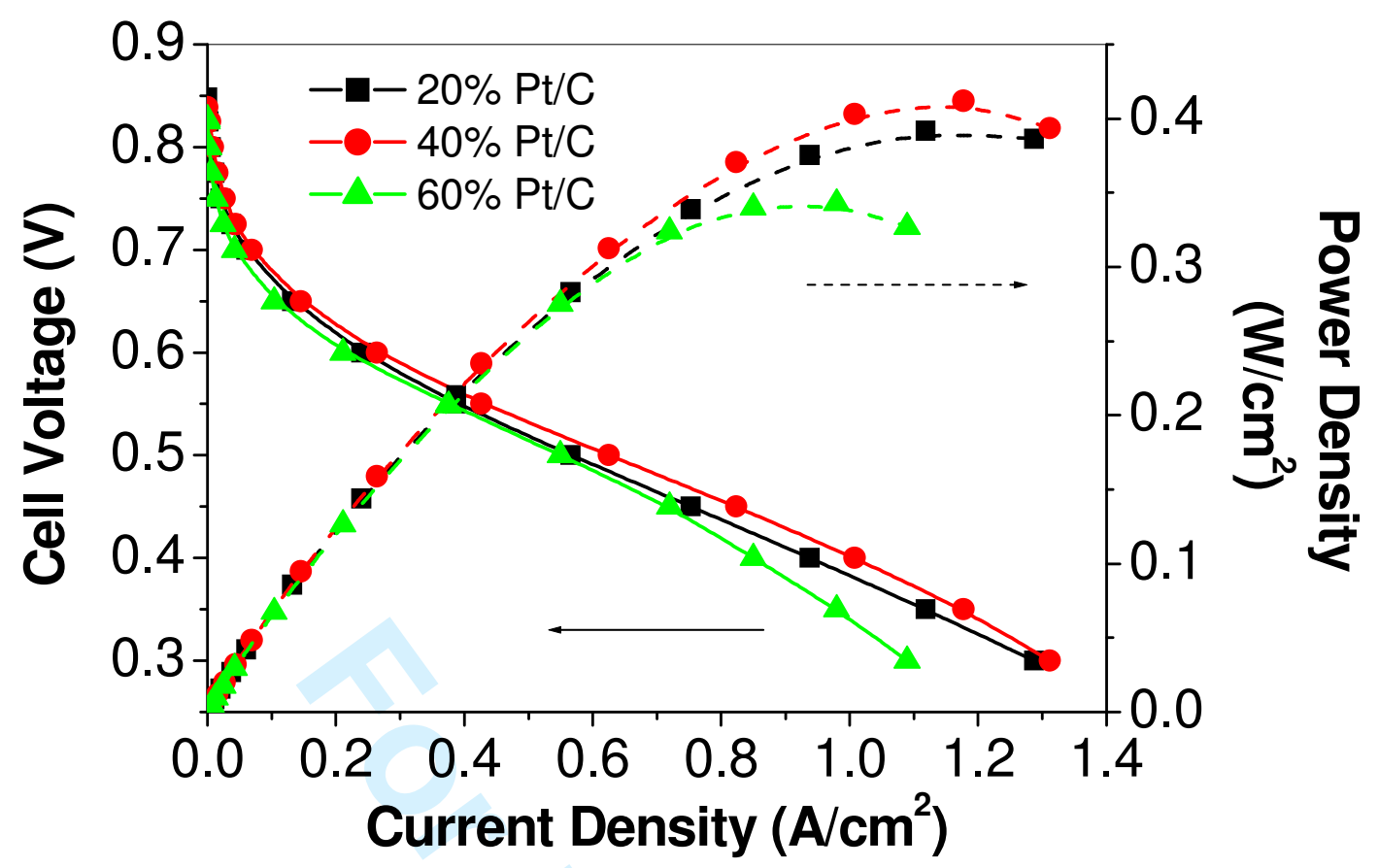

Figure 5 


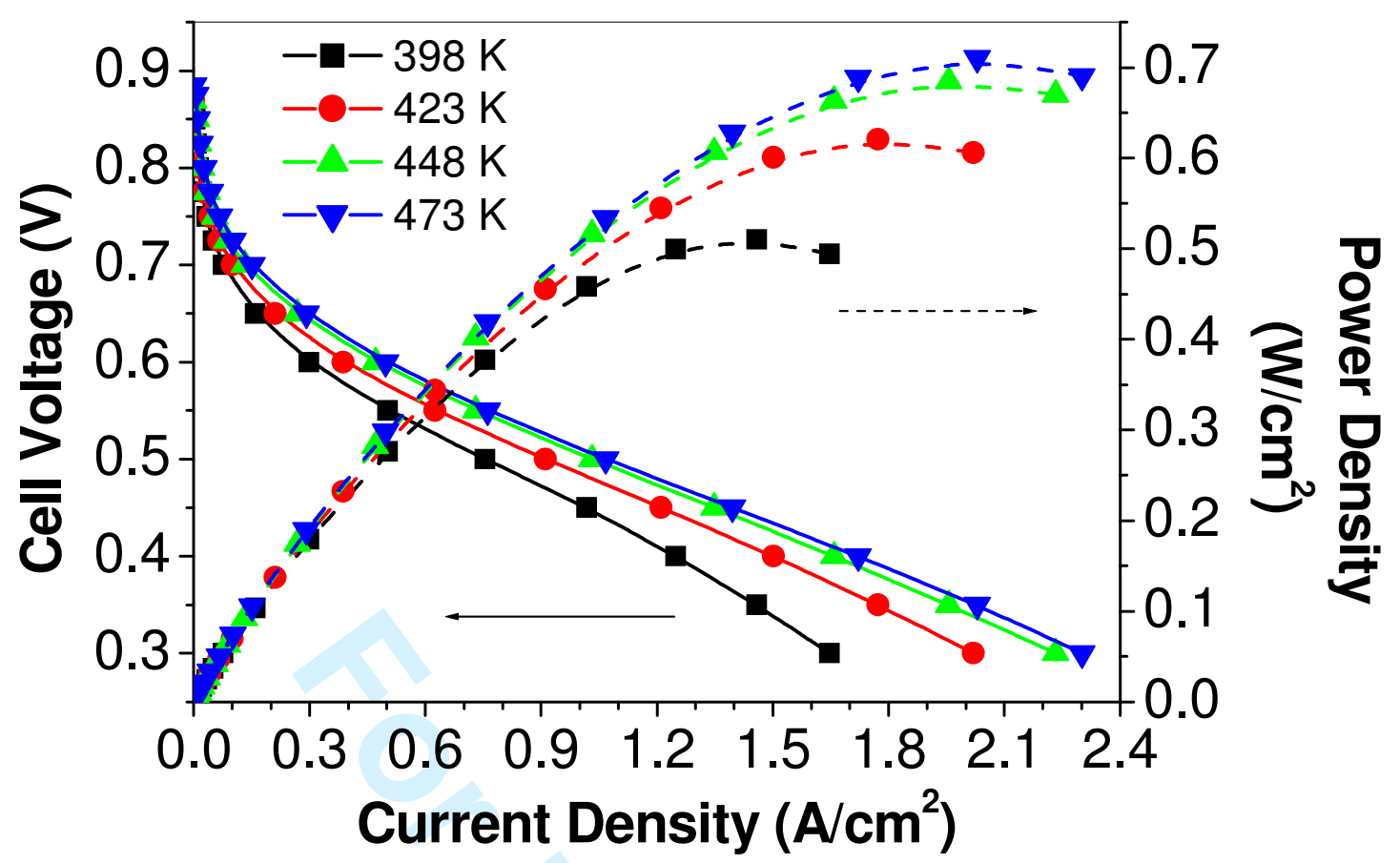

Figure 6 


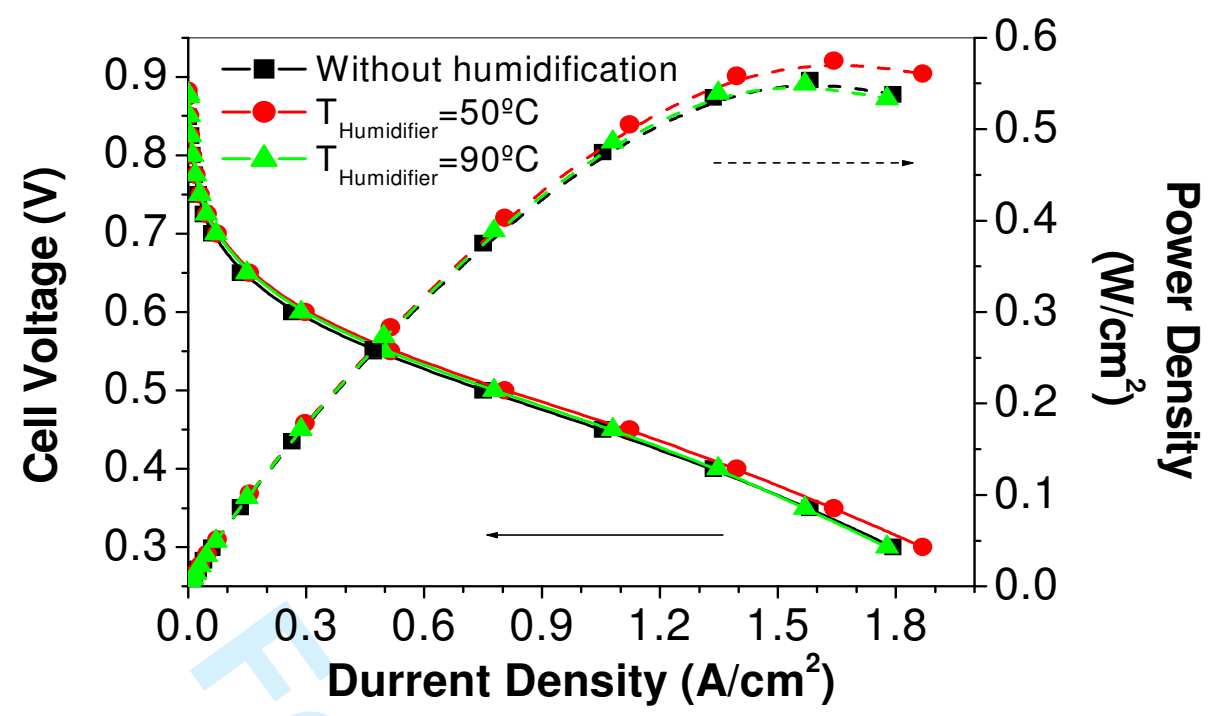

(a)

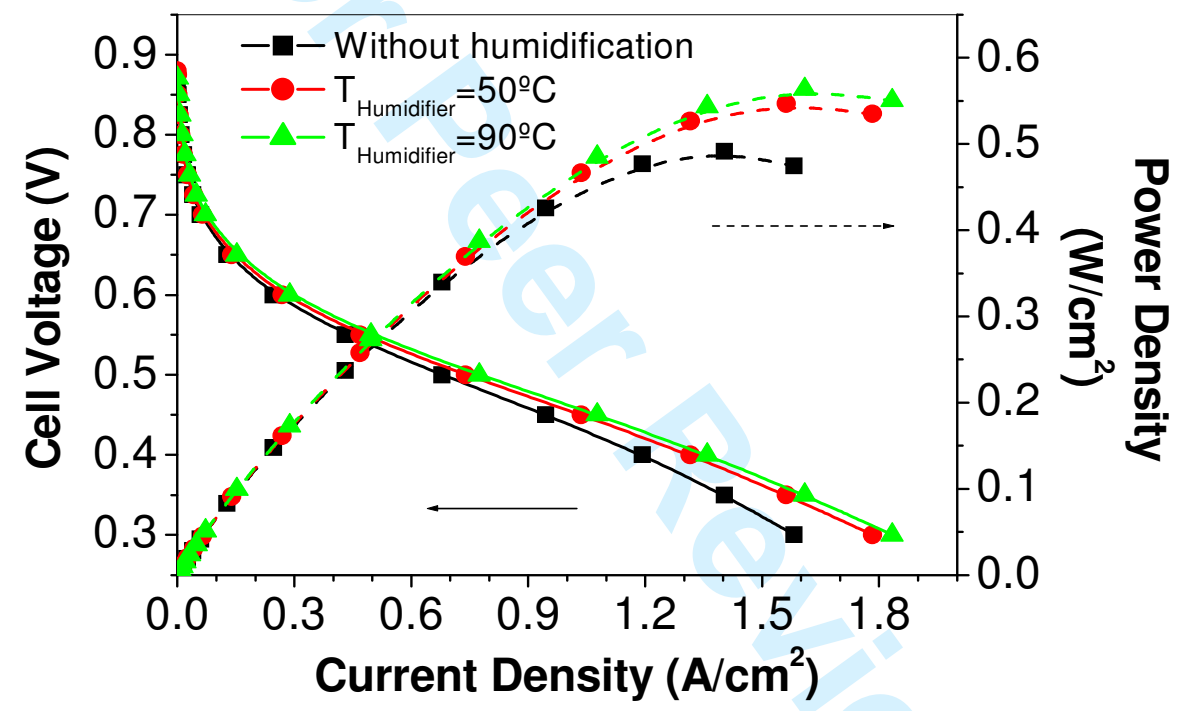

(b)

\section{Figure 7}


Table 1

\begin{tabular}{|c|c|c|c|}
\hline & & $\% \mathrm{Pt} / \mathrm{C}$ & \\
\hline & 20 & 40 & 60 \\
\hline Porosity (\%) & 55.3 & 57.9 & 60.1 \\
\hline Tortuosity (\%) & 4.70 & 4.46 & 4.36 \\
\hline Mean pore size $(\mu \mathrm{m})$ & 30.3 & 31.2 & 31.8 \\
\hline ESA $\left(\mathrm{m}^{2} / \mathrm{g} \mathrm{Pt}\right)$ & 54.8 & 50.8 & 41.2 \\
\hline Diameter of Pt particles (nm) & 2.2 & 2.9 & 3.7 \\
\hline $\begin{array}{c}\text { Available catalyst surface area }\left(\mathrm{m}^{2}\right. \\
\left.\mathbf{g}_{\mathrm{Pt}^{\prime}}\right)^{*}\end{array}$ & 120 & 100 & 78 \\
\hline Platinum utilisation $(\%)$ & 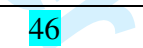 & 50 & 52 \\
\hline Estimated catalyst thickness $(\mu \mathrm{m})$ & 49 & 18 & 8 \\
\hline $\mathrm{b}(\mathrm{mV} / \mathrm{dec})(1)$ & 69.3 & 68.2 & 74.0 \\
\hline b (mV/dec) (2) & 86.2 & 84.0 & 98.7 \\
\hline$R_{p, c}\left(\Omega \cdot \mathrm{cm}^{2}\right)(1)$ & 0.102 & 0.097 & 0.169 \\
\hline $\mathbf{R}_{\mathrm{p}, \mathrm{c}}\left(\Omega \cdot \mathrm{cm}^{2}\right)(2)$ & 0.373 & 0.355 & 0.611 \\
\hline
\end{tabular}

(1) $\mathrm{O}_{2}$ as comburent

(2) Air as comburent

* Provided by manufacturer 
Table 2

\begin{tabular}{|c|c|c|c|c|}
\hline & \multicolumn{4}{|c|}{ Temperature } \\
\cline { 2 - 5 } & $\mathbf{3 9 8} \mathbf{~}$ & $\mathbf{4 2 3} \mathbf{~ K}$ & $\mathbf{4 4 8} \mathbf{~}$ & $\mathbf{4 7 3 ~ K}$ \\
\hline $\mathbf{E}_{\mathbf{0}}(\mathbf{m V})$ & 913.4 & 921.1 & 938.0 & 955.3 \\
\hline $\mathbf{1 0}^{\mathbf{5}} \mathbf{j}_{\mathbf{0}}\left(\mathbf{m A} / \mathbf{c m}^{2}\right)$ & 5.96 & 6.23 & 11.7 & 30 \\
\hline $\mathbf{b}(\mathbf{m V} / \mathbf{d e c})$ & 70.2 & 68.7 & 69.2 & 72.3 \\
\hline $\mathbf{R}\left(\mathbf{\Omega} \mathbf{c m}^{2}\right)$ & 0.193 & 0.165 & 0.155 & 0.150 \\
\hline
\end{tabular}

